DOI: 10.12731/wsd-2017-3-47-61

UDC 631.41

\title{
FEATURES OF HUMUS AND NITROGEN ECOLOGICAL STATUS FOR STEPPE ZONE CHERNOZEMS OF THE NORTH CAUCASUS ${ }^{1}$
}

\author{
Novikov A.A.
}

The purpose of the paper presented is to determine tendency and intensity for quantitative and qualitative changes in humus and nitrogen status of chernozems. The system approach to study natural objects is assumed as the basis for research methodology of humus and nitrogen status of soils.

It is established that the depth typical values of chernozem humus horizons in the North Caucasus are 120-180 cm for South European facies of leached chernozems, 100-170 cm for modal chernozems, 70-160 cm for common chernozems, 70-120 cm for southern chernozems; for East European facies of southern chernozems the value is 55-70 cm. A distinctive ecological feature of the soils is thought to be a low humus content in the arable layer, its deep distribution along the profile and slight variability among each subtype.

Nitrogen quantity in chernozems of the region variates within a comparatively wide range: $0.20-0.35 \%$ in South European facies of leached, modal and common chernozems, 0.22-0.30\% in East European facies of southern chernozems. Southern chernozems of South European facies contain least of all nitrogen, i.e., $0.18-0.22 \%$. Total nitrogen composition is mainly presented by non-hydrolysable facies, making 74.2-78.9\%.

The research materials are intended to design farming systems on the landscape basis for specialists dealing with the issues of soil preservation, increasing soil fertility as well as environment protection. The results of the research may contribute to making a purposeful impact on decision making to control humus and nitrogen status of soils, thus serving as the basis for preservation of bioecological potential of chernozems.

Keywords: soil; soil fertility; chernozems; humus; nitrogen.

${ }^{1}$ Новиков А.А. Особенности экологического состояния гумуса и азота чернозёмов степной зоны Северного Кавказа // В мире научных открытий, 2016. № 12(84). С. 144-160. doi:10.12731/wsd-2016-12-144-160. 


\title{
ОСОБЕННОСТИ ЭКОЛОГИЧЕСКОГО СОСТОЯНИЯ ГУМУСА И АЗОТА ЧЕРНОЗЁМОВ СТЕПНОЙ ЗОНЫ СЕВЕРНОГО КАВКАЗА
}

\author{
Новиков А.А.
}

Цель представленной работы установить направленность и интенсивность количественных и качественных изменений гумусного и азотного состояний чернозёмов. В основу методологии исследований гумусного и азотного состояния почв положен системный подход к изучению объектов природы.

Установлено, что типичные значения мощности гумусовых горизонтов чернозёмов Северного Кавказа составляют: южно-европейской фаиии выщелоченных 120-180, типичных 100-170, обыкновенных 70-160, южных 70-120, восточно-европейской фачии южных 55-70 см. Отличительная экологическая особенность почв - низкое содержание гумуса в пахотном слое, глубокое распределение его по профилю, малая вариабельность среди каждого подтипа.

Количество азота в чернозёмах региона колеблется сравнительно в широких пределах: в южно-европейской фащии выщелоченных, типичных, обыкновенных 0,20-0,35\%; восточно-европейской фаџии южных 0,220,30. Меньше всего азота содержат чернозёмы южные южно-европейской фации -0,18-0,22\%. Состав валового азота в основном представлен негидролизуемой фракиией - 74,2-78,9\%.

Материалы исследования предназначены для проектирования систем земледелия на агроландшафтной основе, специалистам занимающимся вопросами сохранения и повышения плодородия почв, охраны окружающей среды. Результаты исследования позволяют осуществлять ичеленаправленное воздействие на принятие решений по регулированию гумусного и азотного состояния почв, что послужит основой сохранения биоэкологического потеничиала чернозёмов.

Ключевые слова: почва; плодородие почв; чернозёмьг; гумус; азот.

\section{Introduction}

V.V. Dokuchaev, a prominent soil analyst and natural scientist, repeatedly noted that chernozem is the basis of Russia's wealth and prosperity. However, for a long period of time, we have, especially recently, been facing a number 
of significant problems concerning chernozems fertility, namely, progressive degradation of the soil, dehumification, loss of organic and readily available mineral forms of nitrogen, which have resulted in development of other negative processes and are mainly responsible for the current decline in productivity and sustainability of the agroecosystem.

It is the ecological problem of fertility preservation along with its main indicators, i.e., humus and nitrogen in the chernozems of the North Caucasus, being among the most fertile soils both in Russia and all over the globe, that is becoming increasingly urgent. Thus, both generalization and monitoring the humus and nitrogen status of the chernozems in the region are required.

\section{Purpose}

To establish the direction and intensity of both quantitative and qualitative changes in the humus and nitrogen status of the chernozems of the North Caucasus.

\section{Study data and methodology}

The methodology of the research concerning the humus and nitrogen status of soils is based on a systematic approach to the study of objects of nature that points out the necessity not to isolate an object or phenomenon, but to consider it in its interrelation and interdependence with the surrounding systems and processes.

The following components constitute the basis of the methodology for studying the humus and nitrogen status of chernozems that determine the level of soil fertility, its bioenergy potential, sustainable ecological functioning of the agroecosystem, as well as land protection:

- integrated approach to biological objects, i.e., soil derivatives and abiotic environment;

- profile-genetic and comparative-geographical assessment of soil status;

- taking into account spatial and temporal variability of soil properties;

- consistency of author's research methods.

The research activities were carried out as the fieldwork on common and southern chernozems at the three stations of the Don Zonal Research Institute of Agriculture. Soil crossovers were made at the stations and allocated lots to be used to take soil samples according to GOST (All-Union State Standard) 28168-89. Following "The general sampling procedure requirements" (GOST 29269-91), the samples were used to determine common humus (GOST 2621391), total nitrogen (GOST 26107-84), as well as fraction-group composition of humus using the method by I.V. Tyurin as modified by V.V. Ponomaryova and 
T.A. Plotnikova. The mathematic treatment of the findings was carried out using a technique developed by B.A. Dospekhov.

\section{Results of the study and their discussion}

Organic matter performs an enormous number of functions. It serves as a direct source of nutrients for plants, affects nutrients accessibility and behavior, regulates soil structure formation, its hydrophysical properties, thermal parameters, redox and ion exchange reactions $[1,2]$.

Considering the environmental aspect, it is especially important that humus substances are characterized by their high absorption capacity, thus (as well as other colloid substances) contributing to one of the most remarkable properties of the soil, i.e., its buffering capacity, the ability to withstand the harmful effects of acidic and alkaline solutions [3].

Soil, once it is enriched with organic matter, becomes more resistant to contamination due to a high content of various functional groups in humic acids, including carboxyl, amine, phenolic, hydroxyl groups, involved in the formation of simple and complex organo-mineral compounds [4].

Organic matter is characterized by having general significance for the globe as it constitutes "humosphere" which is thought to be the most important natural storage of energy, being essential to help plants obtain mineral nutrition elements out of inaccessible forms, i.e., nitrogen out of air, ash constituents out of minerals of soil-forming materials [5].

At present, bioenergetics issues are becoming increasingly relevant, which is due to both general environmental problems and specific practical tasks of preserving and improving soil fertility and productivity of crops $[6,7]$.

Sources of soil organic matter and energy it contains are the remains of plants, animals, microorganisms and their products that are subjected to complex, sometimes opposite, transformations $[8,9,10,11]$.

During the decomposition process of organic substances in the soil, processes of mineralization and the so-called "aging" of both newly formed humus substances and previously accumulated ones are observed. As a result of mineralization of the "destructive" (i.e. annually decomposing) humus, as well as decomposition of decaying plans and other organic compounds, a certain amount of substances enters the soil. Their level depends not only and not so much on the total amount of humus as on the amount of the humus part and total organic matter that dissolve.

New portions of humification products enter into exchange reactions with the already existing humic acids, as well as with the exchangeable and non-ex- 
changeable occluded mineral part of the soil, participate in the completion and fragmentation of the renewed humus substances, perform the protective function of the "old" humus as it were. Along with plant and animal remains, soil receives energy fixed by photosynthesis [12].

It is the loss of the main property of natural soils, i.e. the rhythm of destruction of a part of humus and formation of a new part within the same year, that is the main ecological criterion for the deterioration of the humus status of plowed soils.

According to G. Reuter, the loss of humus in soils as a result of long-term use amounts to $13-25 \%$ of the original content [13]. In Canada, the humus content in the arable land has decreased by an average of $45 \%$ within the past 50 years, including chernozems by $48.2 \%$; in soils of the south of the USA the humus content has decreased to $60 \%$.

Over the last 70-80 years, the loss of humus in the arable soils of the USSR amounted to $40-50 \%$, different subtypes of chernozems annually lost $0.5-1.8$ tons per hectare $[14,15]$.

Most studies of the humus status of the North Caucasus chernozems were carried out in the areas of the warm Southern European facies, while the others were conducted in the areas of the warm-temperate Eastern European facies.

The study of the humus status of soils of the Southern Russia showed that its formation was determined by a complex of natural historical prerequisites, the most important being rank motley grass and fescue-feather grass vegetation with well-developed root system. The remains of the latter were humified for a long time in warm and warm-temperate climate.

It was established that the greatest thickness of the humus horizon characterizes chernozems of the leached Southern European facies, reaching $180 \mathrm{~cm}$. Lesser A+B thickness of 100-170 cm characterizes modal chernozems, common chernozems have even lesser value of $70-160 \mathrm{~cm}$, while southern chernozems are characterized by the value of 70-120 cm thickness of the humus horizon. The least thickness was found in the South Eastern European facies, being 55-70 $\mathrm{cm}[16,17]$.

The typical values of humus of each subtype varies within a just small range. A somewhat larger content of organic matter is characteristic of modal chernozems.

According to the average content of humus and typical values fluctuations modal chernozems are characterized as being low-humic. The scarcely-humic variants of these chernozems are rare, being determined by the lowest values lying beyond the scale of typicality. The extensive area of common and leached 
chernozems of the South European facies is less homogeneous in terms of the humus accumulation intensity.

The southern chernozems of the Southern European and East European facies are mainly low-humic, being considerably different from other soils in the region. The coefficient of variation amounts to $10-28 \%$.

The study of the humus content and its fraction-group composition that we carried out in the common chernozems of the South European facies at the Don Zonal Research Institute of Agriculture as well as southern chernozems of the East European facies at the Severo-Donetsk experimental station showed that common chernozems are characterized by having a considerable thickness of the humus horizon $(84 \mathrm{~cm})$ compared to southern chernozems $(62 \mathrm{~cm})[18$, 19]. Higher value of carbon content and less sharp decrease along the soil profile was also found in common chernozem.

The carbon percentage in the arable horizon of common chernozems amounted to 2.38, while in southern chernozem the value was 2.19; the one in $\mathrm{BC}$ horizon was 0.91 and 0.80 ; in $\mathrm{C}$ it was 0.53 and 0.32 . The amount of humic acid groups in these chernozem subtypes, being equal to $\mathrm{A}_{\text {arable }} 0.98$ and $0.94 \%$, shows a considerable decrease to 0.09 and $0.05 \%$ in $\mathrm{C}$ horizon. The groups of fulvic acids in the $\mathrm{A}_{\text {arable }}$ common and southern chernozems were also approximately equal, i.e. 0.48 and $0.46 \%$, whereas the amount decreased in the lower horizons of the southern chernozem.

The humus type of $\mathrm{A}_{\text {arable }}$ chernozem horizon was found as being humate-fulvic: $R_{h a}: R_{f a}=2.0$. The degree of humification, estimated as the proportion of humic acids in the total amount of carbon, being equal to $41-43 \%$, indicates a "high" conversion degree of organic substances into humic compounds.

As the ratio $\mathrm{R}_{\mathrm{ha}}: \mathrm{R}_{\mathrm{fa}}$ in the lower horizons narrowed, humus in $\mathrm{BC}$ as well as $\mathrm{C}$ horizons acquired properties of the humate-fulvic type.

In the arable horizons of both subtypes of chernozems, the main amount of humic acids is attributed to fraction 2 bonded with calcium in complex forms of compounds, being $0.72-0.69 \%$, whereas southern non-carbonate chernozems are characterized by a slightly lower value. The content value of this fraction in $(\mathrm{A}+\mathrm{B})$ humus horizon was 0.57 and $0.47 \%$, in $\mathrm{C}$ horizon $-0.04-0.02$. The absolute value of fraction 3 , bonded with clay minerals and stable sesquioxides, was $0.210 .20 \%$ in $\mathrm{A}_{\text {arable }}$ of the profile of these soils, while decreasing to $0.05-0.03$ in $\mathrm{C}$ horizon.

The content of free humic acids and humic acids bound with movable sesquioxides of fraction 1 in the arable horizon of common and southern chernozems is quite small (0.05\%), being even lower along the soil profile, in particular, in $\mathrm{B}_{2}$ 
horizon - 0.01; and the fraction was not found at all in $\mathrm{C}$ horizon, which determines the low formation rate of humus substances in the soil profile.

The fulvic part of humus is characterized by approximately similar amount of fraction 2 and 3 fulvic acids in $\mathrm{A}_{\text {arable }}$, i.e., $0.21-0.18$ and $0.20-0.17 \%$, bonded in a complex polymer compound with the corresponding fractions of humic acids. In the lower layers, the percentage of these fractions drops to $0.03-0.06 \%$ in $\mathrm{C}$ horizon, the drop being especially significant in southern chernozems.

The content of fraction 1 , i.e. free humic acids and humic acids bound with movable sesquioxides, as well as fraction 1 is insignificant, amounting to $0.05-0.04 \%$ in $\mathrm{A}_{\text {arable }}, 0.01$ in $\mathrm{C}$ horizon, which indicates the stability of the chernozems organic matter. The amount of insoluble residue in $\mathrm{A}_{\text {arable }}$ and $\mathrm{A}_{1}$ common chernozem horizons is $0.92-0.80$ absolute percent, decreasing to 0.31 in C horizon; concerning southern chernozems the values are $0.79-0.62$ and $0.20 \%$, respectively. The relative groups and fractions content values while a part of carbon compositions correspond to their percentage in soils, being characteristic of these subtypes of chernozems.

The proportion of humic acids in the total amount of carbon in the upper horizon is slightly lower in common chernozems (41\%) compared to southern chernozems (43\%), in the humus horizon it amounts to 38.2 and $37.5 \%$ respectively, while in $\mathrm{C}$ horizon the proportion is $17-15.6 \%$.

The relative content of the fulvic acids group amounts to $20.2-21.0 \%$ in $\mathrm{A}_{\text {arable }}, 20.8$ and $22.2 \%$ in the humus horizon, i.e. the content value is somewhat larger in southern chernozems, whereas in C horizon, on the contrary, the value is slightly less in southern chernozems $(22 \%)$ compared to common chernozems $(24.5 \%)$, which indicates a large migratory capacity of fulvic acids in this type of chernozem.

As a part of their humic acids in $(\mathrm{A}+\mathrm{B})$ humus horizon, southern chernozems contain $68.3 \%$ of fraction 2 , whereas common chernozems contain $73 \%$ of fraction 2 . The proportion of other fractions, especially fraction 1 , is relatively small.

Concerning the fulvic part, the relative content of fractions 2 and 3 in $\mathrm{A}_{\text {arable }}$ is the same in both subtypes, namely, 8.8-7.6 and 9.1-7.8\%, their amount increasing along the profile in common chernozems, especially in $\mathrm{BC}$ horizon (fraction 2) and $\mathrm{C}$ horizon (fraction 3). The same phenomenon can be observed in southern chernozems, except for BC horizon, which contains less fraction 2 compared to $\mathrm{A}_{\text {arable }}$.

The relative percentage of fraction $1_{\mathrm{a}}$ and fraction 1 is low. No significant changes in the content of these fractions along the profile of common cher- 
nozems were observed, their amount increasing in southern chernozems, for example, the one of fraction 1increased from $1.8 \%$ in $\mathrm{A}_{\text {arable }}$ to 3.1 in $\mathrm{C}$.

The percentage of insoluble residue, amounting to $38.6 \%$ in $\mathrm{A}_{\text {arable }}$ of common chernozems, increases to $58.5 \%$ in $\mathrm{C}$ horizon, from $36.1 \%$ in $\mathrm{A}_{\text {arable }}$ to $62.5 \%$ in $\mathrm{C}$ horizon, which proves the lesser mobility degree of the organic matter of this type of chernozem [20].

Nitrogen is the biogenic element, its transformation being entirely determined by the processes of humus formation and mineralization, as well as the biochemical activity of the soil. This clearly affects the nature of nitrogen compounds of the soil, that mainly consists of organic forms (93-97\%), most of them being a part of humus $[21,22,23]$.

Formation of the nitrogen bulk of the main subtypes of the chernozems in the South of Russia is determined by a complex of soil formation conditions, the main components being a deeply penetrating vegetation root system and favorable climatic conditions.

Typical values of the total nitrogen content in the arable horizon of leached chernozems are $0.20-0.35 \%$. Common chernozems, as well as modal and southern of Eastern European facies are characterized by somewhat narrower fluctuations ranges of these values. In southern chernozems of the Southern European facies, when compared to other soils, the nitrogen content proves to be lower, while its fluctuations range is also narrower, the variation coefficient being $18-26 \%$ [24].

Specific data on particular soil crossovers of the North Caucasus show their regional specific features and differences from chernozems in the European part of Russia, i.e., a relatively low content of both nitrogen and humus in the arable layer, as well as its deep and gradual decrease along the genetic horizons.

Both leached and modal chernozems of Krasnodar Krai contain approximately the same amount of total nitrogen, i.e., in $0.23-0.21 \%$ in $\mathrm{A}_{\text {arable }}, 0.14$ $0.13 \%$ in $\mathrm{AB}_{1}$ horizon at a depth of $75-80 \mathrm{~cm}, 0.09 \%$ in $\mathrm{B}_{1}$ horizon at a depth $125-130 \mathrm{~cm}$. In common chernozem crossovers, the amount of nitrogen in the soil layer $0-10 \mathrm{~cm}$ is slightly larger than in leached and modal chernozems, being $0.28 \%$. The decrease of nitrogen down along the soil profile is proportional, but its distribution is deeper in comparison to leached chernozems; thus, the nitrogen content in the layer of $70-80 \mathrm{~cm}$ was $0.18 \%, 120-130 \mathrm{~cm}-0.13 \%$, $150-160 \mathrm{~cm}-0.08 \%$.

Modal chernozems of Stavropol Krai are characterized by the same values of total nitrogen content in the upper horizon, just as leached and modal cher- 
nozems of the region do. Down along the soil profile, the amount of nitrogen also gradually decreased, being $0.13 \%$ in $\mathrm{AB}_{1}$ horizon at a depth of $80-90 \mathrm{~cm}$. In common chernozems, within the layer of $0-20 \mathrm{~cm}$ there is more nitrogen than in modal chernozems, though its distribution along the soil layers is the same.

The amount of nitrogen in the arable layer of common and southern chernozems of Rostov Oblast was found as being $0.25-0.24 \%$ and $0.12-0.08 \%$ in $\mathrm{BC}$ horizon.

The analysis of particular crossovers fractional composition of the North Caucasus region chernozems showed that leached chernozems of the Southern European facies of Krasnodar Krai that contain $0.149 \%$ total nitrogen in $\mathrm{A}_{\text {arable }}$ were characterized as having mere $7 \mathrm{mg}$ mineral forms (N-NH4 ++ N-NO3-) per $100 \mathrm{~g}$ of soil, i.e., just $0.4 \%$ of total content. The share of more accessible organic forms as represented by easily hydrolysable fraction (amines, a certain part of the amides) was $16.1 \mathrm{mg}$ per $100 \mathrm{~g}$ of soil, i.e., $8.3 \%$ of $\mathrm{N}_{\text {total }}$.

It was found that there is twice as much hardly hydrolysable form of nitrogen, being a secondary reserve for plants nutrition, than easily hydrolysable in both absolute and relative values. The major part of nitrogen (145.3 mg per 100 g, i.e., $74.9 \%$ of $\mathrm{N}_{\text {total }}$ ) is represented by a non-hydrolysable fraction, which only slightly participates in the biological cycle.

As compared to $\mathrm{A}_{\text {arable }}$, the amount of mineral nitrogen slightly increased in $\mathrm{A}_{1}$ horizon, whereas it dropped in $\mathrm{B}_{1}$ horizon to $0.5 \mathrm{mg}$ per $100 \mathrm{~g}$ of soil and to $0.3 \mathrm{mg}$ per $100 \mathrm{~g}$ of soil in $\mathrm{B}_{2}$ and $\mathrm{C}$. Its share in the total nitrogen amount increased insignificantly in $\mathrm{A}_{1}$ horizon, whereas it decreased slightly in deeper horizons, having the same value, except for $\mathrm{C}$ horizon.

The amount of the easily hydrolysable nitrogen fraction in the lower part of the humus horizon $\left(\mathrm{B}_{2}\right)$ was found as $5.5 \mathrm{mg}$ per $100 \mathrm{~g}$ of soil and $2.3 \mathrm{in} \mathrm{C}$ horizon. The relative value of this form in the lower horizons also decreased, though less sharply than the absolute one.

The content of hardly hydrolysable and non-hydrolysable nitrogen in their absolute value, as well as easily hydrolysable nitrogen, decreased along the soil profile, but more gradually. The percentage of these fractions in $\mathrm{N}_{\text {total }}$ had an increasing tendency, except for hardly hydrolysable nitrogen in $\mathrm{BC}$ horizon, its share being the same as in $\mathrm{A}_{\text {arable }}$, and non-hydrolysable nitrogen in the upper part of $A_{1}$, its amount being somewhat less than in $A_{\text {arable }}$.

In common chernozems of Stavropol Krai, the content of total nitrogen within the layer of $0-30 \mathrm{~cm}$ was $0.250 \%$ along with a low share of mineral nitrogen (4.2\% of total) and easily hydrolysable nitrogen $(7.1 \%)$, while the 
content of hardly hydrolysable nitrogen (14.2\%) and non-hydrolysable nitrogen $(74.4 \%)$ was high.

The absolute amount of total, mineral, easily hydrolysable and hardly hydrolysable nitrogen decreased in lower soil layers, except for mineral nitrogen in the layer of 30-40 cm that contains a bit more of this fraction compared to the layer of $0-30 \mathrm{~cm}$. The amount of non-hydrolysable nitrogen decreased in its absolute value along the soil layers from $0-30 \mathrm{~cm}$ to $40-50 \mathrm{~cm}$, while the relative value increased in layers of $30-40 \mathrm{~cm}$ and $40-50 \mathrm{~cm}$.

The amount of total nitrogen in $\mathrm{A}_{\text {arable }}$ of chernozems obtained at the stations of the Don Zonal Research Institute of Agriculture was found as $0.250 \%$, which is just the same as the one found for common chernozems of Stavropol Krai, whereas the amount of mineral nitrogen is less, being $2.4 \mathrm{mg}$ per $100 \mathrm{~g}$ of soil. Along the soil profile, the amount of total nitrogen in C horizon drops to $0.080 \%$, while the amount of mineral nitrogen decreases to $0.8 \mathrm{mg}$ per $100 \mathrm{~g}$ of soil. The share of the mineral nitrogen fraction in $\mathrm{N}_{\text {total }}$ hardly varied along the horizons.

The fractions of easily hydrolysable, hardly hydrolysable and non-hydrolysable nitrogen varied along the soil profile the same way as total and mineral nitrogen did. As a percentage of total nitrogen, the content of non-hydrolysable fractions increased, while the one of easily hydrolysable fraction decreased, the hardly hydrolysable fraction changing but a little.

$\mathrm{A}_{\text {arable }}$ of southern chernozems contained $0.220 \%$ of total nitrogen, $13.3 \mathrm{mg}$ per $100 \mathrm{~g}$ of soil of easily hydrolysable nitrogen and $29.6 \mathrm{mg}$ per $100 \mathrm{~g}$ of soil of hardly hydrolysable nitrogen, which is less than in common chernozem, while the share of mineral nitrogen was higher. The absolute and relative amounts of mineral nitrogen fraction along the soil layers increased, being more noticeable in $\mathrm{B}_{1}$ horizon compared to $\mathrm{A}_{1}$.

In deeper soil horizons, organic fractions underwent certain changes just the way they did in common chernozems, though their quantitative characteristics being more significant. Their share in $\mathrm{N}_{\text {total }}$ along the depth of the soil is approximately of the same value. The content of non-hydrolysable nitrogen, as well as other fractions, compared to common chernozems is lower in $\mathrm{A}_{\text {arable }}$ (173.2 $\mathrm{mg}$ per $100 \mathrm{~g}$ of soil), higher in $\mathrm{B}_{1}(168.2 \mathrm{mg})$ and $\mathrm{B}_{2}(148.4 \mathrm{mg}$ per $100 \mathrm{~g}$ of soil).

\section{Conclusion}

Thus, both common and southern chernozems, though having certain differences in the total carbon content in the arable layer, are characterized by roughly the same (absolute and relative) composition. The lower horizons con- 
tain a greater absolute quantity of humic and fulvic acids of fractions 2 and 3 as well as insoluble residue in common chernozems compared to southern chernozems, which indicates a more intensive degree of both humus formation and humus compounds fixation.

A study of the nitrogen fractional composition of certain chernozems subtypes of the North Caucasus showed that its composition includes little mineral $(0.4-4.2 \%)$ and easily hydrolysable $(6.0-8.3 \%)$ fractions, though twice as much hardly hydrolysable fraction (13.4-16.4\%). The major part of the nitrogen bulk (74.4-78.9\%) is represented by a non-hydrolysable fraction, which only slightly participates in agricultural crops nutrition.

\section{References}

1. Orlov D.S. Khimiya pochv [Soil chemistry]. Moscow: MGU Publ, 1985, 376 p.

2. Grishina L.A. Gumusoobrazovanie i gumusnoe sostoyanie pochv [Humus formation and humus status of soils]. Moscow: MGU Publ, 1986, $240 \mathrm{p}$.

3. Mineev V.G. Khimizatsiya zemledeliya i prirodnaya sreda [Farming chemization and the environment]. Moscow: Agropromizdat Publ, 1990, 288 p.

4. Aleksandrova L.N. Organicheskoe veshchestvo pochvy i protsessy ego transformatsii [Soil organic matter and processes of its transformation]. Moscow: Nauka Publ, 1980, 287 p.

5. Orlov D.S., Biryukova O.N., Sukhanova N.I. Organicheskoe veshchestvo pochv Rossiyskoy Federatsii [Organic matter of the Russian Federation soils]. Moscow: Nauka Publ, 1996, 256 p.

6. Volodin V.M., Masyutenko N.P. Energeticheskie pokazateli chernozemnykh pochv [Energy indices of chernozem soils]. Doklady Rossel'khozakademii, 1993, no. 6 , pp. $12-15$.

7. Volodin V.M., Shcherbakov A.P., Masyutenko N.P. Energeticheskoe sostoyanie chernozemov TsChZ [Energy status of chernozems in the Central Chernozem Zone]. Antropogennaya evolyutsiya chernozemov [Anthropogenic evolution of chernozems]. Voronezh: 2000, pp. 101-119.

8. Flaiq W., Beutelspacher H., Rietz E. Chemicalcompoition and physical properties of humic substance. In J. E. Giesekibq (ed.), Soil Components. 1975. 1, pp. 1-211. Sprinqer Verlaq, New York.

9. Verma L., Martin J.P. Decomposition of algal cells and compontnts and their stabilization through complexing with model humic acid-tepe phenolic polymers. Soil Biol. Biochem. 1976. 8, pp. 85-90.

10. Shaposhnikova I.M., Novikov A.A. Posleuborochnye ostatki polevykh kul'tur v zernoparopropashnom sevooborote [Post-harvest residues of field crops in 
grain fallow tilled crop rotation]. Agrokhimiya [Agricultural Chemistry], 1985, no. 1 , pp. 48-51.

11. Novikov A.A., Kisarov O.P. Obosnovanie roli kornevykh i pozhnivnykh ostatkov $\mathrm{v}$ agrotsenozakh [Substantation of the role of root and cover residues in agrocenoses]. Nauchnyy zhurnal KubGAU : elektron. nauch. zhurnal. 2012, no. 78(04), pp. 643-652. http://ej.kubagro.ru/2012/04/pdf/36.pdf. (accessed December 12, 2016).

12. R.Teyt III. Organicheskoe veshchestvo pochvy [Soil organic matter]. Moscow: Mir Publ, 1991, 400 p.

13. Reyter G. Zwanzig Jahre Rostocker Dauersuche zur Humusbildung im Boden. Archiv-Acktr und Pflanzenbau und Bodenkunde. 1981. Bd 25. № 5, pp. 277-285.

14. Shcherbakov A.P., Vasenev I.I. Russkiy chernozem na rubezhe vekov [Russian chernozem at the border of ages]. Antropogennaya evolyutsiya chernozemov [Anthropogenic evolution of chernozems]. Voronezh: 2000, pp. 32-67.

15. Babushkin V.M., Krivokoneva E.Yu., Novikov A.A. Prirodnye resursy chernozemov obyknovennykh Yuga Rossii i ikh ratsional'noe ispol'zovanie [Natural resources of common chernozems in the South of Russia and their efficient use]. Novocherkassk: Lik Publ, 2013, 170 p.

16. Novikov A.A. Ekologicheskoe sostoyanie gumusa i azota v chernozemakh Severnogo Kavkaza [Ecological status of humus and nitrogen in chernozems of the North Caucasus]. NGMA. Novocherkassk, 2001, 181 p.

17. Novikov A.A. Gumusnoe sostoyanie pochv v sevooborotakh razlichnoy konstruktsii na chernozemakh obyknovennykh [Humus status of soils in crop rotations of difftrent constructions in common chernozems]. Nauchnyy zhurnal KubGAU elek-tron. nauch. zhurnal. 2012, no. 78(04), pp. 555-564. URL: http: //ej.kubagro.ru/2012/ 04/pdf/34 (accessed December 12, 2016).

18. Shaposhnikova I.M., Novikov A.A., Ignat'ev D.S., Medvedeva V.I. Gumusnoe sostoyanie i azotnyy fond chernozema obyknovennogo [Humus status and and nitrogen bulk of common chernozems]. Agrokhimiya [Agricultural Chemistry]. 2005, no. 5, pp. 15-20.

19. Novikov A.A. Sovremennoe sostoyanie i puti sokhraneniya gumusnogo i azotnogo fonda chernozemov Severnogo Kavkaza [Modern status and ways for conservation of humus and nitrogen funds of chernozems in the North Caucasus]. Novocherkassk, 2002. $317 \mathrm{p}$.

20. Novikov A.A. Ekologo-meliorativnoe sostoyanie chernozemnykh pochv yuzhnogo regiona Rossii [Ecological and reclamation status of chernozems in the southern region of Russia]. LAP LAMBERT Academic Publishinq Publ, 2015, $103 \mathrm{p}$. 
21. Menqel K. Ernahrunq und Stoffwechsel der Pflanze. Jena. 1972, pp. 140-153.

22. Aderikhin P.G., Shcherbakov A.P. Azot v pochvakh Tsentral'no-Chernozemnoy polosy [Nitrogen in soils of the Central Chernozem Zone]. Voronezh, 1974, $170 \mathrm{p}$.

23. Parton W.J., Stewart J.W., Cole C.V. Dynamics of C, N, P, and S in grassland soil. A model. Bioqeochem. 1988. 5, pp. 109-131.

24. Novikov A.A. Formirovanie azotnogo fonda osnovnykh podtipov chernozemov Yuga Rossii [Nitrogen bulk formation for the subtypes of chernozems in the South of Russia]. Nauchnyy zhurnal KubGAU elektron. nauch. zhurn. 2012, no. 78(04), pp. 620-630. http: //ej.kubagro.ru/2012/04/pdf/35.pdf (accessed December 12, 2016).

\section{Список литературы}

1. Орлов Д.С. Химия почв. М.: МГУ, 1985. 376 с.

2. Гришина Л.А. Гумусообразование и гумусное состояние почв. М.: МГУ, 1986. 240 c.

3. Минеев В.Г. Химизация земледелия и природная среда. М.: ВО Агропромиздат, 1990. 288 с.

4. Александрова Л.Н. Органическое вещество почвы и процессы его трансформации. М.: Наука, 1980. 287 с.

5. Орлов Д.С., Бирюкова О.Н., Суханова Н.И. Органическое вещество почв Российской Федерации. М.: Наука, 1996. 256 с.

6. Володин В.М., Масютенко Н.П. Энергетические показатели черноземных почв // Доклады Рос. академии сельскохозяйственных наук. 1993. № 6. C. $12-15$.

7. Володин В.М., Щербаков А.П., Масютенко Н.П. Энергетическое состояние чернозёмов ЦЧЗ // Антропогенная эволюция чернозёмов. Воронеж: 2000. C. 101-119.

8. Flaiq W., Beutelspacher H., Rietz E. Chemicalcompoition and physical properties of humic substance // In J. E. Giesekibq (ed.), Soil Components. 1975. 1, pp. 1-211. Sprinqer Verlaq, New York.

9. Verma L., Martin J.P. Decomposition of algal cells and compontnts and their stabilization through complexing with model humic acid-tepe phenolic polymers // Soil Biol. Biochem. 1976. 8, pp. 85-90.

10. Шапошникова И.М., Новиков А.А. Послеуборочные остатки полевых культур в зернопаропропашном севообороте // Агрохимия. 1985. № 1. С. 48-51.

11. Новиков А.А., Кисаров О.П. Обоснование роли корневых и пожнивных остатков в агроценозах // Научный журнал КубГАУ: электрон. науч. жур- 
нал. 2012. № 78(04). С. 643-652. URL: http: //ej.kubagro.ru/2012/04/pdf/36. pdf. (дата обращения: 12.12.2016).

12. Р. Тейт III. Органическое вещество почвы. М.: Мир, 1991. 400 с.

13. Reyter G. Zwanzig Jahre Rostocker Dauersuche zur Humusbildung im Boden // Archiv-Acktr und Pflanzenbau und Bodenkunde. 1981. Bd 25. № 5. S. $277-$ 285.

14. Щербаков А.П., Васенев И.И. Русский чернозём на рубеже веков // Антропогенная эволюция чернозёмов. Воронеж: 2000. С. 32-67.

15. Бабушкин В.М., Кривоконева Е.Ю., Новиков А.А. Природные ресурсы чернозёмов обыкновенных Юга России и их рациональное использование. Новочеркасск: Лик, 2013. 170 с.

16. Новиков А.А. Экологическое состояние гумуса и азота в чернозёмах Северного Кавказа. НГМА. Новочеркасск: 2001. 181 с.

17. Новиков А.А. Гумусное состояние почв в севооборотах различной конструкции на чернозёмах обыкновенных // Научный журнал КубГАУ: электрон. науч. журнал. 2012. № 78(04). C. 555-564. URL: http: //ej.kubagro. $\mathrm{ru} / 2012 / 04 / \mathrm{pdf} / 34$. (дата обращения: 12.12.2016).

18. Шапошникова И.М., Новиков А.А., Игнатьев Д.С., Медведева В.И. Гумусное состояние и азотный фонд чернозёма обыкновенного // Агрохимия. 2005. № 5. С. 15-20.

19. Новиков А.А. Современное состояние и пути сохранения гумусного и азотного фонда чернозёмов Северного Кавказа: Дис. ... д-ра с.-х. наук. Новочеркасск, 2002. $317 \mathrm{c}$.

20. Новиков А.А. Эколого-мелиоративное состояние чернозёмных почв южного региона России. LAP LAMBERT Academic Publishinq, 2015. 103 c.

21. Menqel K. Ernahrunq und Stoffwechsel der Pflanze // Jena. 1972, pp. 140-153.

22. Адерихин П.Г., Щербаков А.П. Азот в почвах Центрально-Черноземной полосы. Воронеж, 1974. 170 с.

23. Parton W.J., Stewart J.W., Cole C.V. Dynamics of C, N, P, and S in qrassland soil // A model. Bioqeochem. 1988. 5, pp. 109-131.

24. Новиков А.А. Формирование азотного фонда основных подтипов чернозёмов Юга России // Научный журнал КубГАУ: электрон. науч. журнал. 2012. № 78(04). C. 620-630. URL: http: //ej.kubagro.ru/2012/04/pdf/35.pdf. (дата обращения: 12.12.2016).

\section{DATA ABOUT THE AUTHOR}

Novikov Aleksei Alekseevich, Doctor of Agriculture, Professor at the Chair of Cadastre and Monitoring of Lands 
Novocherkassk Institute of Reclamation Engineering after A.K. Kortunov, Donskoi State Agrarian University

111, Pushkinskaya Str., Novocherkassk, Rostov region, 346428, Russian Federation

al.al.novikov@gmail.com

SPIN-code: 6731-7692

ORCID: 0000-0001-9013-2629

\section{ДАННЫЕ ОБ АВТОРЕ}

Новиков Алексей Алексеевич, доктор сельскохозяйственных наук, профессор кафедры кадастра и мониторинга земель

Новочеркасский инженерно-мелиоративный институт имени А.К. Кортунова - филиал федерального государственного бюджетного образовательного учреждения высшего образования «Донской государственный аграрный университет»

ул. Пушкинская, 111, г. Новочеркасск, Ростовская область, 346428 , Российская Федерация

al.al.novikov@gmail.com 